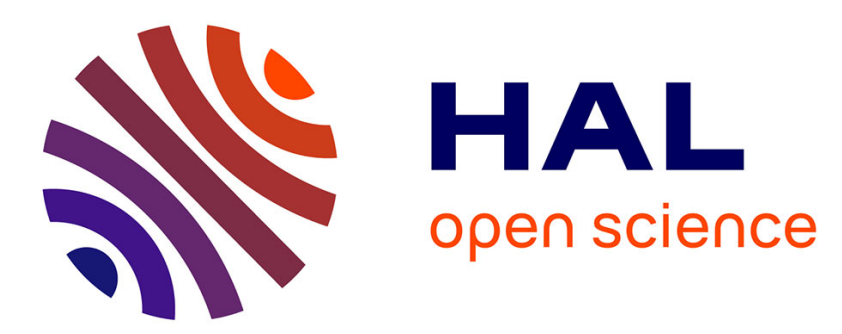

\title{
Expression of heat shock protein 70 in a permanent cell line (EPC) exposed to sediment extracts from the North Sea and the Baltic Sea
}

\author{
A. Kinder, A. Sierts-Herrmann, S. Biselli, N. Heinzel, H. Hühnerfuss, U. \\ Kammann, N. Reineke, N. Theobald, H. Steinhart
}

\section{To cite this version:}

A. Kinder, A. Sierts-Herrmann, S. Biselli, N. Heinzel, H. Hühnerfuss, et al.. Expression of heat shock protein 70 in a permanent cell line (EPC) exposed to sediment extracts from the North Sea and the Baltic Sea. Marine Environmental Research, 2007, 63 (5), pp.506. 10.1016/j.marenvres.2005.08.004 . hal-00501814

\section{HAL Id: hal-00501814 https://hal.science/hal-00501814}

Submitted on 12 Jul 2010

HAL is a multi-disciplinary open access archive for the deposit and dissemination of scientific research documents, whether they are published or not. The documents may come from teaching and research institutions in France or abroad, or from public or private research centers.
L'archive ouverte pluridisciplinaire HAL, est destinée au dépôt et à la diffusion de documents scientifiques de niveau recherche, publiés ou non, émanant des établissements d'enseignement et de recherche français ou étrangers, des laboratoires publics ou privés. 


\section{Accepted Manuscript}

Expression of heat shock protein 70 in a permanent cell line (EPC) exposed to sediment extracts from the North Sea and the Baltic Sea

A. Kinder, A. Sierts-Herrmann, S. Biselli, N. Heinzel, H. Hühnerfuss, U.

Kammann, N. Reineke, N. Theobald, H. Steinhart

PII:

S0141-1136(07)00027-X

DOI:

10.1016/j.marenvres.2005.08.004

Reference:

MERE 3100

To appear in:

Marine Environmental Research

Received Date:

10 December 2004

Revised Date:

2 August 2005

Accepted Date:

11 August 2005

Please cite this article as: Kinder, A., Sierts-Herrmann, A., Biselli, S., Heinzel, N., Hühnerfuss, H., Kammann, U., Reineke, N., Theobald, N., Steinhart, H., Expression of heat shock protein 70 in a permanent cell line (EPC) exposed to sediment extracts from the North Sea and the Baltic Sea, Marine Environmental Research (2007), doi: 10.1016/ j.marenvres.2005.08.004

This is a PDF file of an unedited manuscript that has been accepted for publication. As a service to our customers we are providing this early version of the manuscript. The manuscript will undergo copyediting, typesetting, and review of the resulting proof before it is published in its final form. Please note that during the production process errors may be discovered which could affect the content, and all legal disclaimers that apply to the journal pertain. 


\title{
Expression of heat shock protein 70 in a permanent cell line (EPC) exposed to sediment extracts from the North Sea and the Baltic Sea
}

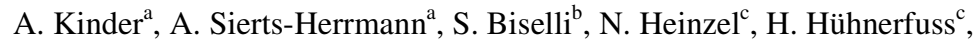 \\ U. Kammann ${ }^{\text {d }}$, N. Reineke ${ }^{\mathrm{c}}$, N. Theobald ${ }^{\mathrm{b}}$, H. Steinhart ${ }^{\mathrm{a}}$ * \\ ${ }^{a}$ University of Hamburg, Institute of Biochemistry and Food Chemistry, Grindelallee 117, 20146 Hamburg, Germany \\ ${ }^{\mathrm{b}}$ German Federal Maritime and Hydrographic Agency, Wuestland 2, 22589 Hamburg, Germany \\ ${ }^{c}$ University of Hamburg, Institute of Organic Chemistry, Martin-Luther-King-Platz 6, 20146 Hamburg, Germany \\ ${ }^{\mathrm{d}}$ Federal Research Centre for Fisheries, Institute for Fishery Ecology, Palmaille 9, 22767 Hamburg, Germany
}

*To whom correspondence should be addressed.

Tel: $+49-40-42838-4357$

Fax: +49-40-42838-4342

E-mail address: hans.steinhart@ chemie.uni-hamburg.de 


\section{ABSTRACT}

Heat shock proteins 70 (hsp70) are known to be induced by a great variety of chemical stressors. The effects of different environmental contaminants, which were identified in sediments of the North Sea and the Baltic Sea as main contaminants or as contaminants of special toxicological interest, on the extent of expression of hsp70 in a permanent cell line Epithelioma papulosum cyprini (EPC) were investigated. Concentrations of the single contaminants leading to elevated hsp70 levels were compared to the respective concentrations of these contaminants encountered in the sediment extracts thus allowing an assessment of their contribution to the toxicitiy of these sediments. Analysis of hsp70 was performed using western blotting techniques with subsequent comparative quantification by densitometry. Eleven of thirteen contaminants have shown a dose-dependent increase in hsp70 levels. An expression of hsp70 was observed in most cases between $0,1-10 \mu \mathrm{g} / \mathrm{mL}$ test solution. Some of the investigated stressors led to extremely high hsp70 contents even at low concentrations. However, in most cases contaminant concentrations in sediments were too low to cause an effect. For this reason, effects of the tested sediments are attributed to other contaminants or rather to mixtures of stressors.

Keywords: EPC, marine sediment, Heat shock proteins, bioassay, sediment toxicity, sublethal stress

\section{INTRODUCTION}

A multitude of anthropogenic substances reaches the North Sea and the Baltic Sea and leads to a considerable burden on the marine environment. Sediments function as both a sink and, in the case of remobilisation, as a source. Many national and international monitoring programmes include the analysis of contaminants that are known to be toxic and / or persistent. Chemical analysis alone is insufficient for the assessment of sediment toxicity. It is impossible to determine every anthropogenic contaminant and, furthermore, the effects of most contaminants on the aquatic organisms are still unknown (Ankley et al., 1996). For this reason, the combination of chemical analysis with biological tests becomes important (Fernández et al., 1992; Brack et al., 1999).

Cellular stress protein response, in particular the induction of hsp70, has received increasing attention as a potential marker for sublethal stress, because of its sensitivity to a wide variety of environmental contaminants (Williams et al., 1996; Werner et al., 1998; Marino et al., 1999). Members of the hsp70 family are involved in the cellular protein repair system. They stabilise or 'repair' damaged or aberrant proteins and dissolve protein aggregates present in cells (Ellis, 1990; Gething \& Sambrook, 1992; 
Rutherford \& Zuker, 1994; Hartl, 1996). Increasing occurrence of damaged proteins due to xenobiotics or other forms of stress leads to elevated stress protein content. Numerous inorganic and organic xenobiotics are well known for their ability to induce the synthesis of hsp70 (Salminen et al., 1996; Bierkens et al., 1998; Schröder et al., 1999; Kilemade \& Mothersill, 2001).

The aim of this study was to determine the induction of hsp70 as the result of incubation with two extracts of one North Sea and one Baltic Sea sediment. These sediments differed much from each other regarding to their anthropogenic contamination. While a wide range of contaminants existed in the North Sea sediment, the sediment from the Baltic Sea was mainly contaminated by polycyclic aromatic hydrocarbons (Biselli et al., 2005). In addition to the sediment extracts, several quantitatively dominating contaminants (e.g. polycyclic aromatic hydrocarbons) or substances with structural characteristics of toxicological potential (e.g. quinones, halogenated compounds, sulphides) were selected for individual testing. Single contaminants will be discussed as potential causes for the toxicity observed in the sediment extracts.

\section{MATERIALS AND METHODS}

\section{Chemicals}

All chemicals were of analytical grade and purchased from Sigma-Aldrich (Germany) or Merck (Germany) if not otherwise noted.

\section{Sediment collection and sediment extraction}

The North Sea sediment was collected from the German Bight (5350'N, $\left.8^{\circ} 10^{\prime} \mathrm{E}\right)$ in 2000. The Baltic Sea

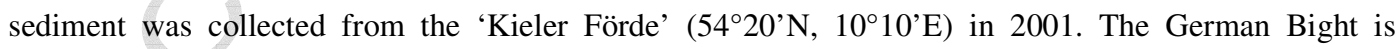
influenced by the rivers 'Elbe' and 'Weser' and a known sink for contaminants coming from these both rivers. The 'Kieler Förde' is in a coastal region and known to be relatively highly contaminated. Sediments were sampled by a box corer with the research vessel 'Gauss' of the German Federal Maritime and Hydrographic Agency. The upper $2 \mathrm{~cm}$ of sediment were collected and stored until extraction at -20 ${ }^{\circ} \mathrm{C}$ in the dark. In the first place pore water was separated by centrifugation $(25 \mathrm{~min}, 3500 \mathrm{x} \mathrm{g})$. With the pore water even inorganic compounds were separated, so the experiments were focused on sediment bound organic contaminants. Afterwards the wet sediment was sequentially extracted with acetone and $n$ hexane by ultraturrax-treatment. Solvents were combined and the water phase was removed by 
refrigeration. Extracts were reduced by rotary evaporation with dimethyl sulfoxide (DMSO) as keeper. Solvent residues were removed under a nitrogen stream. The resulting extracts contained equivalents of about 4 to $5 \mathrm{~g}$ sediment (dry weight) per mL DMSO.

\section{Identification and quantification of single substances}

Identification and quantification of single substances were performed by different methods of GC/MSanalysis. For detailed information see Biselli et al. (2005). The entire procedure (extraction, clean-up, and quantification) was accompanied by suitable methods of quality assurance. All relevant steps of analysis were checked for recovery rates and contaminations. The average recoveries of most PAHs and chlorinated hydrocarbons ranged from 60-100 \%. The accuracy of GC/MS quantification was ascertained by measuring certified standard solutions.

\section{Cell line and cell treatment}

The applied fish cell line 'Epithelioma papulosum cyprini' derived from a skin tumour of carp (Cyprinus carpio L.) was provided by the Collection of Cell Lines in Veterinary Medicine of the Federal Research Centre for Virus Diseases of Animals (Riems, Germany) and was kindly provided by the Federal Research Centre for Fisheries, Institute of Fisheries Ecology. Cells were cultured as described by Kammann et al. (2001). After developing a complete monolayer, cells were trypsinised using Trypsin/EDTA, washed twice with phosphate buffered saline (PBS; $0.1 \mathrm{M} \mathrm{K}_{2} \mathrm{HPO}_{4}, 0.15 \mathrm{M} \mathrm{NaCl}, \mathrm{pH}$ 7.2), resuspended in PBS and distributed to several incubation vessels. By that procedure results proved to be more reproducible as experiments were performed with an homogenous cell suspension. For exposure to sediment extracts or single contaminant test solutions (sediment extracts or solutions of contaminants at concentrations of 0.1 to $10 \mu \mathrm{g} / \mathrm{mL}$ DMSO) were added to resuspended cells in duplicate. Since DMSO, under the described conditions, led to an hsp70-expression at concentrations higher than 2 $\%$ (data not shown), a DMSO concentration of $1 \%$ was chosen for all experiments. Incubation time was 2 $\mathrm{h}$ at room temperature. In previous investigations this incubation time prove to be sufficient for an hsp70expression. Longer incubation times yielded a slight increase of hsp70-levels until a decrease due to cytotoxic effects (data not shown). In addition, hsp70-levels of four to six control groups (depending on the size of the experiment) were determined using untreated cells without incubation. In every experiment an incubation with cadmium chloride $(100 \mu \mathrm{M})$ was performed as a positive control to verify the success of the experiment. After incubation cells were washed twice with PBS, resuspended in PBS supplemented 
with $1 \mathrm{mM}$ phenylmethylsulfonyl fluoride, and homogenised via ultra sonic treatment. A reducing sample buffer (Vieths et al., 1992) was immediately added to each sample at a 1:1 dilution, and samples were boiled for three minutes.

\section{Gel electrophoresis and Western blotting}

The reduced cell suspension containing about $25 \mu \mathrm{g}$ total protein was subjected to a $10 \%$ polyacylamide gel with a $5 \%$ stacking gel (Invitrogen) using the buffer system described by Laemmli (1970). Gels were run at $120 \mathrm{~mA}$ for 35 minutes (Xcell SureLock Mini Cell, Invitrogen).

Proteins were electroblotted onto nitrocellulose membranes (Schleicher\&Schuell, Germany) at a constant current of $180 \mathrm{~mA}$ for $1 \mathrm{~h}$ using a semi-dry blotting apparatus (Invitrogen) in blotting buffer (25 mM Tris, $20 \%$ ethanol; $\mathrm{pH}$ 10.4). Membranes were twice blocked with PBS containing $0.1 \%$ Tween20 and $5 \%$ skimmed milk powder for 15 minutes under permanent shaking and washed twice with double distilled water. Blots were incubated overnight with monoclonal anti-hsp70 directed against bovine hsp70 (BRM22, Sigma). The primary antibody was diluted 1:10,000 with PBS containing $0.1 \%$ bovine serum albumin and $0.05 \%$ Tween20. Blots were then washed three times with PBS containing $0.05 \%$ Tween20. An biotinylated secondary antibody (goat-anti-mouse IgG, Dako; dilution 1:5,000 in PBS containing $0.1 \%$ bovine serum albumin and $0.05 \%$ Tween 20 ; incubation time $3 \mathrm{~h}$ ) was used to detect primary anti-hsp70. After three washing steps blots were incubated with horseradish-peroxidase conjugated streptavidine solution (Medac) diluted 1:20,000 with PBS containing $0.1 \%$ bovine serum albumin and $0.05 \%$ Tween20 for 20 minutes. Hsp70-bands were visualized with the substrate 3,3',5,5'tetramethyl benzidine (Fluka; incubation time approx. 5 minutes). Developed blots were scanned and quantification was performed by densitometric evaluation (Biometra, Scan Pack 3.0) by comparing band areas of samples and an hsp70 standard of bovine brain (Sigma) on the same membrane. For checking transfer efficiency each membrane contained a sample of the control group as well. Variation in bands of equal amounts of hsp70 was approx. $15 \%$, derived from a multiple determination of one sample.

\section{Cytotoxicity}

In preliminary experiments cytotoxicity was detected by the lactate dehydrogenase leakage assay (Sigma). The lactate dehydrogenase activity was determined after incubation and centrifugation in the supernatant with $p$-iodonitrotetrazolium violet as substrate according to Decker \& Lohmann-Matthes 
(1988). Simultanously, the total protein content was measured in cell suspension after homogenisation by the method of Bradford (1976) and expressed as percentage of control. A good correlation between protein loss and the lactate dehydrogenase leakage assay was observed (data not shown). Cytotoxic effects resulted in a protein loss of more than $20 \%$ referring to the control group. In further experiments the protein content was used as an indicator for cytotoxic effects.

\section{Statistical analysis}

In order to compare toxic effects a threshold concentration of the investigated sediment extracts or the investigated contaminants was determined. The threshold concentration was defined as the concentration of sediment extracts or contaminants calculated from the dose-effect-curves leading to an induction of hsp70 of $150 \%$ with reference to the control group (100\%).

\section{RESULTS}

\section{Induction of hsp70 by incubation with sediment extracts}

The results of the relative induction of hsp70 produced by incubation of EPC-cells with sediment extracts in a range of 0.1 to $50 \mathrm{mg}$ dry weight $/ \mathrm{mL}$ test solution are shown in Fig. 1. In both cases incubation with higher sediment concentrations (4-50 mg dry weight/mL test solution) did not result in significantly elevated hsp70-contents or to cytotoxic effects (data not shown). However, a significant expression of hsp70 was observed after incubation with sediment extracts in the range between 0.2 and 1-4 mg dry weight/mL test solution. In this range hsp70-contents up to $175 \%$ relative to the control group were measured. Threshold concentrations of approx. $0.25 \mathrm{mg}$ dry weight $/ \mathrm{mL}$ test solution (North Sea) and approx. $0.7 \mathrm{mg}$ dry weight $/ \mathrm{mL}$ test solution (Baltic Sea) were determined from the dose effect relationships.

\section{Induction of hsp70 by selected contaminants found in the North Sea and the Baltic Sea sediments}

The results of the application of selected contaminants to EPC-cells are summarized in Table 1. Presented results show that the tested substances exerted different effects on the induction of hsp70.

Hsp70 was induced by nearly all compounds tested except for $N, N$ '-diethyl- $N, N^{\prime}$-diphenyl urea and 1,3,4,6,7,8-hexahydro-4,6,6,7,8,8-hexamethyl-cyclopenta[g]-2-benzopyran $\quad$ (HHCB, $\quad$ galaxolide $^{\circledR}$ ). 
Cytotoxic effects were caused by benzanthrone and HHCB in the highest concentrations applied to EPCcells.

Remarkable effects were measured after incubation of EPC-cells with tris(2-chloroethyl)phosphate and 2methylthiobenzothiazole. These compounds, especially 2-methylthiobenzothiazole, led to a strong expression of hsp70, up to approximately 20 -fold increase in content compared to the controls. In all other experiments in this study, the expression of hsp70 did not exceed $250 \%$ compared to the control. Furthermore, significantly elevated hsp70 levels were observed for these compounds as well as for fluoranthene over nearly the whole range tested, whereas in contrast after incubation with the other compounds significantly increased hsp70 levels were determined at one to three concentrations. Also noteworthy is the fact, that in some cases the maximum induction was not associated with the highest concentrations of contaminants. Only in case of the compounds phenanthrene, 9,10-phenanthrene quinone, 4-bromo phenol, tris(2-chloroethyl)phosphate, and carbazole the concentration of $10 \mu \mathrm{g} / \mathrm{mL}$ test solution induced maximal elevated hsp70 levels of about 1.5 to 5-fold compared to controls. During exposure to 3-methyl quinoline and benzanthrone highest expression of hsp70 was observed at a concentration of $5 \mu \mathrm{g} / \mathrm{mL}$ test solution. A test solution of $2 \mu \mathrm{g} / \mathrm{mL}$ led to the maxima of the dose-effectrelationship in the case of pyrene, dieldrine, and 2-methylthiobenzothiazole, while after exposure to fluoranthene the maximum of hsp70 induction was observed at $1 \mu \mathrm{g} / \mathrm{mL}$ test solution.

\section{DISCUSSION}

The dose-effect relationships resulting from exposure to crude sediment extracts as well as from incubation with single contaminants showed a similar development. After having reached the threshold concentration a dose dependent increase in expression of hsp70 up to a maximum of induction was observed. Further increasing concentrations led to a decrease in hsp70 expression down to contents of the control group or even lower contents. However, in the latter case this can be attributed to cytotoxic effects. The curve described above was observed after exposure to both sediment crude extracts and to the single contaminants 3-methyl quinoline, pyrene, fluoranthene, 2-methylthiobenzothiazole, dieldrine, and benzanthrone. In the case of phenanthrene, 9,10-phenanthrene quinone, 4-bromo phenol, tris(2chloroethyl)phosphate, and carbazole the maximum of induction was reached with the highest concentrations, so an equivalent cytotoxic response is still possible if higher concentrations of these substances were applied to the test. 
The observed dose relationship for hsp70 expression was described for numerous single substances such as heavy metals (Eckwert et al., 1997), paracetamol (Neuhaus-Steinmetz \& Rensing, 1997), sodium dodecyl sulfate (Vijayan et al., 1998), oxyfluorfen (Hassanein et al., 1999), and sodium arsenite (Edwards et al., 1990) in other investigations. To date, a dose-effect relationship resulting from incubation with complex mixtures like sediment extracts have not been noted by the authors.

Eckwert et al. (1997) subdivided the curve of hsp70 expression into three zones. The first zone, at low concentrations of contaminants, shows no increase in hsp70 contents. Any samll damage is compensated by existing levels of hsp70 or just marginal induction of hsp70. In the second zone hsp70 levels increase drastically due to the cellular damage caused by higher concentrations of stressors. The maximum of hsp70 expression is reached at the end of this zone. In the third zone hsp70 expression decreases down to control or even lower levels. The decrease in hsp70 expression is partly due to strong damage of the cells' protein synthesis apparatus required for hsp70 synthesis (Meyer et al., 1995). Marked pathological damage is also partly responsible for the reduction in hsp70 (Pawert et al., 1996; Triebskorn \& Köhler, 1996). Cytotoxic effects like membrane damage lead to decreasing hsp70 contents compared to control groups (Köhler et al., 1996).

In this study no decrease in hsp70 levels compared to control groups was observed in the case of sediment extract exposure. After having returned to the control levels of hsp70 at a distinct sediment concentration, this level stayed the same even at higher sediment concentrations. Another kind of effect, an inhibition of hsp70 synthesis, may be responsible for this result. An inhibition of the hsp70 synthesis by substances like glycerol, copper and some flavonoids was described by several research groups (Edington et al., 1989; Hosokawa et al., 1990; Sanders \& Martin, 1994). Werner et al. (1998) observed a negative correlation between hsp60 induction and some organotin compounds between expression of hsp70 and benzo[b,k]fluoranthene and benzo[ghi]perylene after exposure of 23 sediments to amphipods (Ampelisca abdita), respectively. There was a suggestion of an inhibition by some polycyclic aromatic hydrocarbons in the course of a bioassay-directed fractionation (data not shown). Specific substances from complex mixtures leading to an inhibition of hsp70 syntheses still need to be determined.

In conclusion, the observed shape of the dose-effect-curve makes it clear, that measured effects depend on the concentration tested. To avoid false conclusions, the analysis at different concentrations is essential, regardless whether testing single contaminants or complex mixtures. The procedure of determing threshold concentrations for complex mixtures requires that substances, which inhibit the hsp70- 
synthesis, are not included - but this is not practicable for samples of unknown composition. Altogether, the mentioned aspects show that hsp70-induction is not a practical marker for analysis of complex mixtures.

Comparison of the concentrations of contaminants leading to hsp70 inductions and concentrations in sediments

In Table 2 the minimal concentrations of the tested contaminants leading to a significant expression of hsp70 are compared to the concentrations existing in the test solution during exposure to sediment extracts. Obviously, no single contaminant is responsible for the observed effects. On the other hand, effects in sediment crude extracts were even determined at dilutions of 1:100 and more. Only for the contaminants fluoranthene, pyrene and tris(2-chloroethyl)phosphate is a contribution to an effect produced by the undiluted crude extract feasible (Table 2). The results suggest that the effects observed after exposure to the two sediment extracts can probably be traced back to a mixture of various contaminants present in the sediment, rather than to a single substance.

\section{ACKNOWLEDGEMENTS}

This work was supported by the German Ministry for Education, Science, Research, and Technology (BMBF, project 'ISIS', F0271A-C). Furthermore, we thank and Mrs. Regina Hanke, Mrs. Sünje Staack, and Mrs. Denise Pein for technical assistance, and Mrs. Kerstin Kusian for cultivating the cells.

\section{REFERENCES}

Ankley, G.T., DiToro, D.M., Hansen, D.J., \& Berry, W.J. (1996) Assessing the ecological risk of metals in sediments. Environmental Toxicology \& Chemistry, 15, 2053-2055.

Bierkens, J., Maes, J., \& Vander Plaetse, F. (1998) Dose-dependent induction of heat shock protein 70 synthesis in Raphidocelis subcapitata following exposure to different classes of environmental pollutants. Environmental Pollution, 101, 91-97.

Biselli, S., Reineke, N., Heinzel, N., Kammann, U., Franke, S., Hühnerfuss, H., \& Theobald, N (2005). Bioassay-directed-fractionation of organic extracts of marine surface sediments from the North Sea and Baltic Sea- Part I: Determination and identification of organic pollutants. Journal of Soils and Sediments, OnlineFirst <DOI: http://dx.doi.org/10.1065/jss2004.10.124.1> 
Brack, W., Altenburger, R., Ensenbach, U., Möder, M., Segner, H., \& Schüürmann, G. (1999) Bioassaydirected identification of organic toxicants in river sediment in the industrial region of Bitterfeld (Germany) - A contribution to hazard assessment. Archives of Environmental Contamination \& Toxicology, 37, 164-174.

Bradford, M.M. (1976) A rapid and sensitive method for the quantitation of microgram quantities of protein utilizing the principle of protein-dye binding. Analytical Biochemistry, 72, 248-254.

Decker, T., \& Lohmann-Matthes, M.L. (1988) A quick and simple method for the quantitation of lactate dehydrogenase release in measurements of cellular cytotoxicity and tumor necrosis factor (TNF) activity. Journal of Immunological Methods, 15, 61-69.

Eckwert, H., Alberti, G., \& Köhler, H.-R. (1997) The induction of stress proteins (hsp) in Oniscus asellus (Isopoda) as a molecular marker of multiple heavy metal exposure: I. Principles and toxicological assessment. Ecotoxicology, 6, 249-262.

Edington, B.V., Whelan, S.A., \& Hightower, L.E. (1989) Inhibition of heat shock (stress) protein induction by deuterium oxide and glycerol: additional support for the abnormal protein hypothesis of induction. Journal of Cell Physiology, 139, 219-227.

Edwards, M.J., Dykes, P.J., Donovan, M.R.O., Merrett, V.R., Morgan, H.E., \& Marks, R. (1990) Induction of heat shock proteins as a measure of chemical cytotoxicity. Toxicology in vitro, 4, $270-276$.

Ellis, R.J. (1990) The molecular chaperon concept. Seminar in Cell Biology 1, 1-7.

Fernández, P., Grifoll, M., Solanas, A.M., Bayona, J.M., \& Albaiges, J. (1992) Bioassay-directed chemical analysis of genotoxic components in coastal sediments. Environmental Science \& Technology, 26, 817-829.

Gething, M.-J., \& Sambrook, J. (1992) Protein folding in the cell. Nature, 355, 33-42.

Hartl, F.U. (1996) Molecular chaperones in cellular protein folding. Nature, 381, 571-579.

Hassanein, H.M.A., Banhawy, M.A., Soliman, F.M., Abdel-Rehim, S.A., Müller, W.E.G., \& Schröder, H.C. (1999) Induction of Hsp70 by the herbicide oxyfluorfen (Goal) in the Egyptian Nile Fish, Oreochromis niloticus. Archives of Environmental Contamination \& Toxicology, 37, 78-84.

Hosokawa, N., Hirayoshi, K., Nakai, A., Hosokawa, Y., Marui, N., Yoshida, M., Sakai, T., Nishino, H., Aoike, A., Kawai, K., \& Nagata, K. (1990) Flavonoids inhibit the expression of heat shock proteins. Cell Structure \& Function, 15, 393-401.

Kammann, U., Bunke, M., Steinhart, H., \& Theobald, N. (2001) A permanent fish cell line (EPC) for genotoxicity testing of marine sediments with the comet assay. Mutation Research, 498, 67-77.

Kilemade, M., \& Mothersill, C. (2001) Heat shock protein 70 levels in rainbow trout primary epidermal cultures in response to 2,4-dichloraniline exposure: A novel in vitro aquatic toxicity marker. Environmental Toxicology, 16, 253-259. 
Köhler, H.-R., Rahman, B., Gräff, S., Berkus, M., \& Triebskorn, R. (1996) Expression of the stress-70 protein family (hsp70) due to heavy metal contamination in the slug, Deroceras reticulatum: an approach to monitor sublethal stress conditions. Chemosphere, 33, 1327-1340.

Laemmli, U.K. (1970) Cleavage of structural proteins during the assembly of the head of bacteriophage T4. Nature, 227, 680-685.

Mariño, F., Winters, C., \& Morgan, A.J. (1999) Heat shock protein (hsp60, hsp70, hsp90) expression in earthworms exposed to metal stressors in the field and laboratory. Pedobiologia, 43, 615-624.

Meyer, U., Schweim, P., Fracella, F., \& Rensing, L. (1995) Close correlation between heat shock response and cytotoxicity in Neurospora crassa treated with aliphatic; alcohols and phenols. Applied Environmental Microbiology, 61, 979-984.

Neuhaus-Steinmetz, U., \& Rensing, L. (1997) Heat shock protein induction by certain chemical stressors is correlated with their cytotoxicity, lipophilicity and protein-denaturing capacity. Toxicology, 123, 185-195.

Pawert, M., Triebskorn, R., Gräff, S., Berkus, M., Schulz, J., \& Köhler, H.-R. (1996) Cellular alterations in Collembolan midgut cells as a marker of heavy metal exposure: ultrastructure and intracellular metal distribution. Science of the Total Environment, 181, 187-200.

Rutherford, S.L., \& Zuker, C.S. (1994) Protein folding and the regulation of signaling pathways. Cell, 79, 1129-1132.

Salminen, W.F., Voellmy, R., \& Roberts, S.M. (1996) Induction of hsp 70 in HepG2 cells in response to hepatotoxicants. Toxicology \& Applied Pharmacology, 141, 11-123.

Sanders, B.M., \& Martin, L.S. (1994) Copper inhibits the induction of stress protein synthesis by elevated temperatures in embryos of the sea urchin Strongylocentrotus purpuratus. Comparative Biochemistry \& Physiology, 109C, 295-307.

Schröder, H.C., Batel, R., Lauenroth, S., Hassanein, H.M.A., Lacorn, M., Simat, T., Steinhart, H., \& Müller, W.E.G. (1999) Induction of DNA damage and expression of heat shock protein HSP70 by polychlorinated biphenyls in the marine sponge Suberites domuncula Olivi. Journal of Experimental Marine Biology \& Ecology, 233, 285-300.

Triebskorn, R., \& Köhler, H.-R. (1996) The impact of heavy metals on the grey garden slug Deroceras reticulatum (Müller): metal storage, cellular effects and semi-quantitative evaluation of metal toxicity. Environmental Pollution, 93, 327-343.

Vieths, S., Schöning, B., Brockmann, A., \& Aulepp, H. (1992) Untersuchungen zur Allergie gegen Lebensmittel pflanzlicher Herkunft: Herstellung und Charakterisierung von Obst- und Gemüseextrakten für serologische Untersuchungen. Deutsche Lebensmittel Rundschau, 88, 239243 und 273-279.

Vijayan, M.M., Pereira, C., Kruzynski, G., \& Iwama, G.K. (1998) Sublethal concentrations of contaminant induce the expression of hepatic heat shock protein 70 in two salmonids. Aquatic Toxicology, 40, 101-108. 


\section{ACCEPTED MANUSCRIPT}

Werner, I., Kline, K.F., \& Hollibaugh, J.T. (1998) Stress protein expression in Ampelisca abdita (Amphipoda) exposed to sediments from San Francisco Bay. Marine Environmental Research, 45, 417-430.

Williams, J.H., Farag, A.M., Stansbury, M.A., Young, P.A., Bergman, H.L., \& Petersen, N.S. (1996) Accumulation of Hsp70 in juvenile and adult rainbow trout gill exposed to metal-contaminated water and/or diet. Environmental Toxicology \& Chemistry, 15, 1324-1328. 


\section{ACCEPTED MANUSCRIPT}

Fig. 1. Dose effect relationships of hsp70-induction and dry weight of the investigated sediment extracts applied to the bioassay. Cells were exposed for two hours to several concentrations of dry weight $/ \mathrm{mL}$ test solution. A -Sediment of the German Bight (North Sea); B - Sediment of the Kieler Förde (Baltic Sea). Represented is the range of Hsp70 levels determined by two individual experiments.
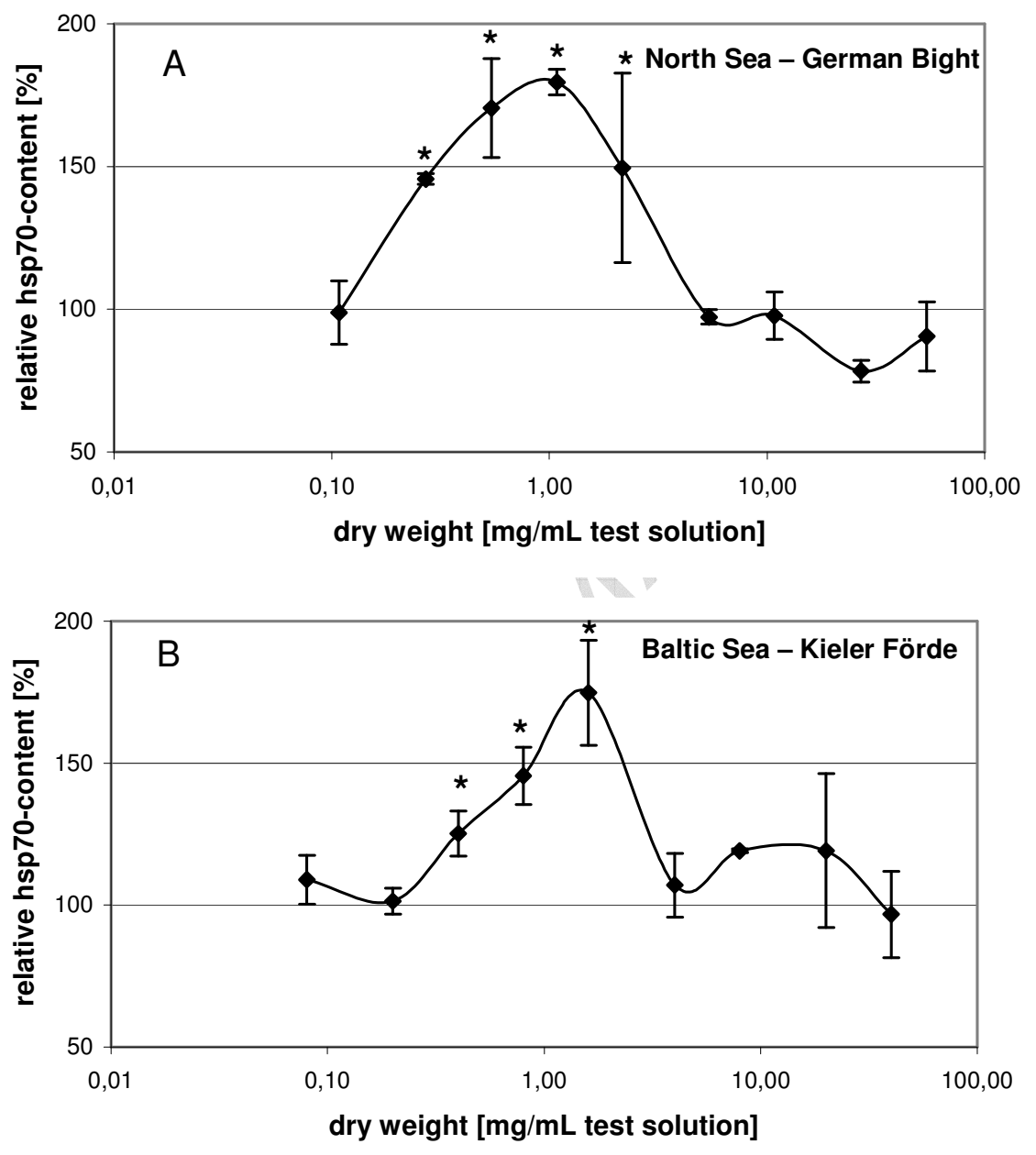
TABLE 1

Expression of hsp70 after a two hours exposure to various contaminants of the North Sea and the Baltic Sea.

\begin{tabular}{lccccccc}
\hline Contaminants $(\mu \mathrm{g} / \mathrm{mL}$ test solution) & 0.1 & 0.2 & 0.5 & 1 & 2 & 5 & 10 \\
\hline Phenanthrene & 108 & 103 & 99 & 113 & 122 & $\mathbf{1 2 9}$ & $\mathbf{1 5 4}$ \\
9,10-Phenanthrene quinone & 111 & 97 & 103 & 103 & 112 & $\mathbf{1 5 0}$ & $\mathbf{1 8 0}$ \\
3-Methyl quinoline & 101 & 109 & 107 & 103 & $\mathbf{1 4 7}$ & $\mathbf{2 3 1}$ & $\mathbf{1 6 8}$ \\
Pyrene & 75 & 104 & 117 & $\mathbf{1 2 0}$ & $\mathbf{1 7 9}$ & $\mathbf{1 3 0}$ & 89 \\
Fluoranthene & 100 & $\mathbf{1 1 3}$ & $\mathbf{1 2 8}$ & $\mathbf{2 5 4}$ & $\mathbf{2 0 0}$ & $\mathbf{1 8 8}$ & $\mathbf{1 4 9}$ \\
4-Bromophenol & 98 & 90 & 107 & 100 & 126 & 138 & $\mathbf{1 5 3}$ \\
Tris(2-chloroethyl)phosphate & 99 & $\mathbf{1 3 2}$ & $\mathbf{1 3 5}$ & $\mathbf{1 7 0}$ & $\mathbf{4 2 0}$ & $\mathbf{4 8 6}$ & $\mathbf{5 2 3}$ \\
N, $N^{\prime}$-diethyl- $N, N^{\prime}$-diphenyl urea & 105 & 94 & 108 & 103 & 90 & 97 & 99 \\
HHCB (Galaxolide ${ }^{(3)}$ & 107 & 95 & 100 & 113 & 107 & 113 & $\underline{103}$ \\
2-Methylthiobenzothiazole & $\mathbf{1 3 2}$ & $\mathbf{1 8 3}$ & $\mathbf{1 9 7}$ & $\mathbf{2 2 5}$ & $\mathbf{2 1 8 3}$ & $\mathbf{6 8 3}$ & $\mathbf{2 4 5}$ \\
Dieldrine & 104 & 108 & 108 & $\mathbf{1 5 0}$ & $\mathbf{1 8 3}$ & 137 & 93 \\
Benzanthrone & 109 & 108 & 104 & 97 & 99 & $\mathbf{1 4 7}$ & $\underline{76}$ \\
Carbazole & 87 & 99 & 92 & 103 & 111 & $\mathbf{1 2 3}$ & $\mathbf{1 4 5}$
\end{tabular}

Hsp70 values are shown as mean relative contents according to the control group $(n=2)$. Bold numbers show hsp70-contents significantly elevated to control $(p<0.05)$. Underlined numbers show cytotoxic effects. 


\section{ACCEPTED MANUSCRIPT}

Table 2

Comparison of concentrations of contaminants leading to an expression of hsp70 with the concentrations in the sediment extract applied to EPC-cells.

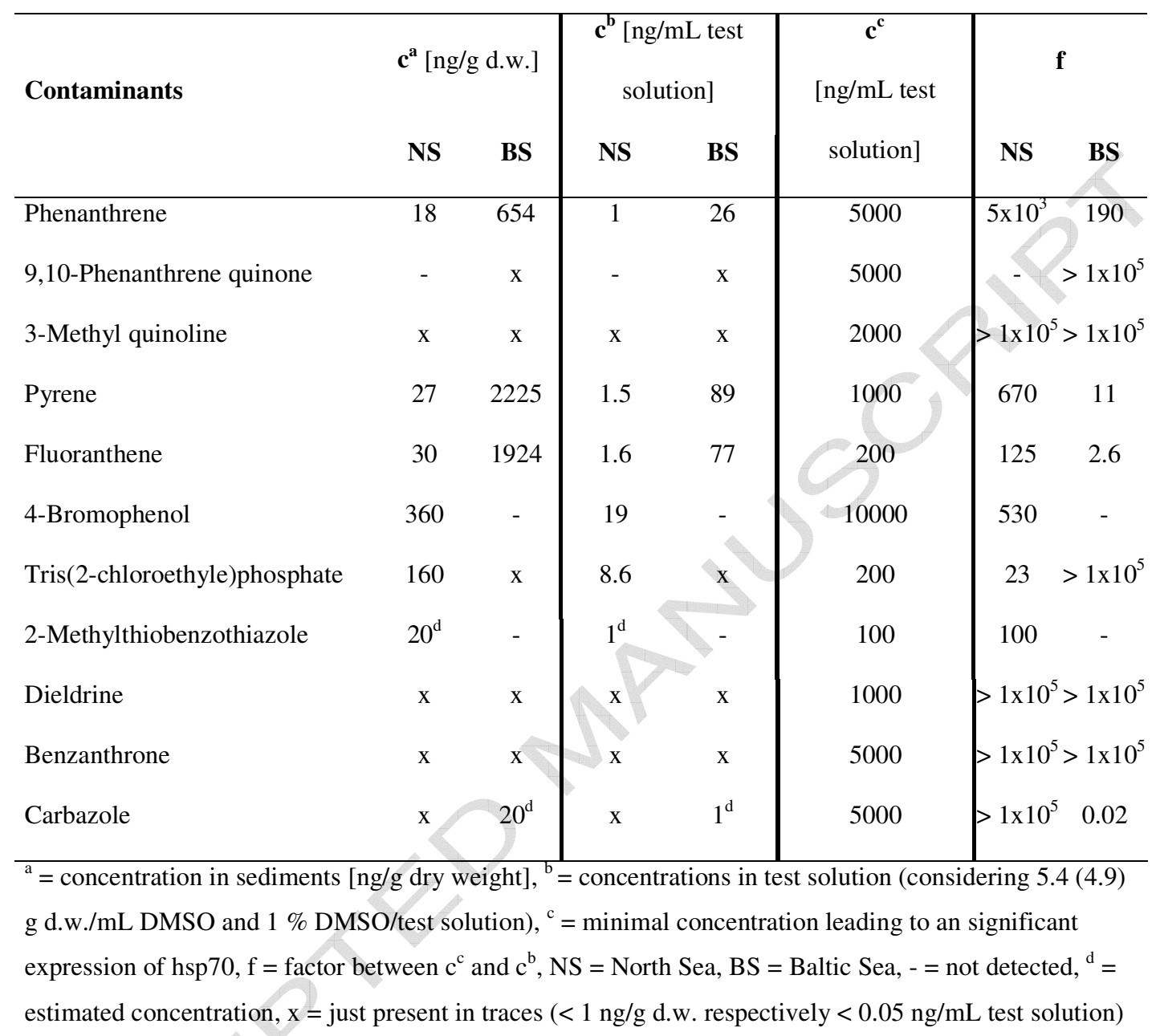

